\title{
Development of Microbial Augmentation for the Treatment of Recalcitrant Industrial Wastewater Containing Chlorinated Organic Compounds
}

\author{
Hyun Don Lee, Seong Won Im and Hyun-Hyo Suh* \\ Department of Evironmental Engineering, Gyeongnam National University of Science and Technology, Jinju 660-758, Korea
}

Received July 7, 2014 /Revised August 4, 2014 /Accepted August 5, 2014

\begin{abstract}
The screening of the microorganisms degrading chlorinated organic compounds such as PCP (pentachlorophenol) and TCE (trichloroethylene) was conducted with soil and industrial wastewater contaminated with various chlorinated organic compounds. Isolates (GP5, GP19) capable of degrading PCP and isolates (GA6, GA15) capable of degrading TCE were identified as Acetobactor sp., Pseudomonas sp., Arthrobacer sp., Xanthomonas sp. and named Acetobacter sp. GP5, Pseudomonas sp. GP19, Arthrobacer sp. GA6 and Xanthomoas sp. GA15, respectively. The microbial augmentation, OC17 formulated with the mixture of bacteria including isolates (4 strains) degrading chlorinated organic compounds and isolates (Acinetobacter sp. KN11, Neisseria sp. GN13) degrading aromatic hydrocarbons. Characteristics of microbial augmentation OC-17 showed cell mass of $2.8 \times 10^{9} \mathrm{CFU} / \mathrm{g}$, bulk density of $0.299 \mathrm{~g} / \mathrm{cm}^{3}$ and water content of $26.8 \%$. In the experiment with an artificial wastewater containing PCP $(500 \mathrm{mg} / \mathrm{l})$, degradation efficiency of the microbial augmentation OC17 was $87 \%$ during incubation of 65 hours. The degradation efficiency of TCE $(300 \mathrm{uM})$ by microbial augmentation OC17 was $90 \%$ during incubation of 50 hours. In a continuous culture experiment, analysis of the biodegradation of organic compounds by microbial augmentation OC17 in industry wastewater containing chlorinated hydrocarbons showed that the removal rate of COD was $91 \%$ during incubation of 10 days. These results indicate that it is possible to apply the microbial augmentation OC17 to industrial wastewaters containing chlorinated organic compounds.
\end{abstract}

Key words : Chemical oxygen demand, chlorinated organic compounds, continuous culture, microbial augmentation, wastewater treatment

\section{서 론}

최근에 사용이 증가되고 있는 염소화합물, 석유계화합물 등 의 난분해성 유해 화합물들은 분해의 어려움으로 인하여 자연 생태계에 축적됨으로써 환경을 파괴시키고, 생물체에 미치는 독성으로 인하여 환경 - 보건학적으로 큰 문제가 되고 있다. PCP (pentachlorophenol)로 대표되는 폐놀계 염소화합물과 TCE (trichloroethylene)로 대표되는 알켄계 염소화합물은 농 약제조, 섬유산업, 전자산업, 제약산업, 금속산업, 페인트산업, 목재보존 등에 폭넓게 사용되어 왔다[1]. 이런 화합물들은 난 분해성과 생물체에 대한 광범위한 영향력으로 인하여 환경오 염 물질로서 계속적인 관리대상이 되고 있다. 환경오염물질의 처리방법 중에서 미생물의 탁월한 분해 및 무독화 기능을 이 용한 생분해(biodegradation)는 지하수나 토양과 같은 오염지

\footnotetext{
*Corresponding author

Tel : +82-55-751-3340, Fax : +82-55-751-3484

E-mail : hhsuh@gntech.ac.kr

This is an Open-Access article distributed under the terms of the Creative Commons Attribution Non-Commercial License (http://creativecommons.org/licenses/by-nc/3.0) which permits unrestricted non-commercial use, distribution, and reproduction in any medium, provided the original work is properly cited.
}

의 환경정화에 효과적으로 적용할 수 있을 뿐 아니라 산업폐 수처리에 적용함에 있어서 경제적이고, 환경친화적이라는 장 점을 가지고 있다[1].

페놀계 염소화합물 중에서 대표적인 $\mathrm{PCP}$ 는 살충제와 살균 제로서 주로 목재의 장기보존 용도로 사용되고, 산화적 인산 화작용에 대한 억제작용으로 인하여 생물체에 치명적인 독성 을 나타내며, 잔류성이 강한 주요 환경오염물질의 하나이다 [8]. 폐놀계 염소화합물의 생분해는 고리가 중간대사물질로 쪼 개지고 유기염소가 무기질화 되었을 때 완전한 것으로 간주한 다. 이때 유기화합물로부터 할로겐 치환체의 제거가 중요하 다. 대부분의 방향족 할로겐화합물은 halocatechol로 분해되 며, 분열효소에 의하여 고리의 분열이 일어나고 안정된 탄소할로겐 결합을 형성한 후 할로겐의 이탈이 일어난다. 페놀계 염소화합물의 호기적 분해는 일반적으로 직접 진행되기보다 는 일련의 반응에 의하여 수행된다. 이러한 반응은 첫째, 고리 의 hydroxylation 또는 dioxygenation에 의하여 방향족 염소 화합물의 분해반응에서 핵심 대사물질인 catechol의 형성이 며, 둘째, 방향족 고리의 분열, 셋째, 지방족 중간대사물질로부 터 염소이온의 이탈, 넷째, 생산물은 대사경로로 혼입되어 미 생물 성장에 이용의 연속적 단계를 거쳐 이루어진다[15]. 알켄계 염소화합물의 대표적인 화합물질인 $\mathrm{TCE}$ 는 매우 휘 
발성이 강한 화합물로서 미국 $\mathrm{EPA}$ 가 지정한 10 대 유해화합물 중의 하나이다[15]. TCE는 암을 유발하고 신경계에 치명적인 영향을 미치는 유해화합물로서 이들 화합물 들은 낮은 농도에 서도 생물체에 치명적인 영향을 가져오기 때문에 많은 연구의 대상이 되고 있다[7]. 미생물에 의한 TCE 분해기작은 일반적 인 유기염소계 화합물의 cooxidative metabolism과 유사하며 TCE를 분해하는 효소는 sMMO (soluble methane monooxygenase)와 toluene 2-monooxygenase, toluene 4-monooxygenase, toluene dioxygenase, ammonia monooxygenase 등이 있으며 이들 효소는 Methylosinus trichosporium [17, 20], Pseudomonas cepacia [7], Nitrosomonas europaea [3], Methylocysis parvus [6], Acaligense eutrophus [9] 등의 여러 미 생물에 의해서 생산된다. 이들 미생물들은 각기 다른 분해기 작을 가지고 있고, 이에 따라 각각 제한된 종류의 화합물만을 분해하기 때문에 알켄계 염소화합물의 염소화 정도에 따라 분해효율 및 분해 정도에 차이를 나타낸다. 뿐만 아니라 일정 농도 이상의 기질농도에서는 활성이 현저히 저하되므로 다양 한 유기화합물이 함유된 폐수처리를 위해서는 기질의 종류에 따라서 여러 가지 분해균주의 혼합배양 또는 다기능 분해균주 의 개발이 필요하다.

본 연구에서는 산업폐수 중에 포함된 $\mathrm{PCP}$ 와 $\mathrm{TCE}$ 와 같은 난분해성 유기염소계화합물이 포함되어 있는 산업폐수의 효 과적인 처리를 위하여 자연계로부터 페놀계 염소화합물 PCP 와 알켄계 염소화합물 TCE를 분해할 수 있는 미생물을 탐색하 고, 이들 미생물의 분해특성을 조사하였다. 또한 분리 미생물 들을 혼합하고 제제화하여 다양한 유기염소계화합물들이 포 함되어 있는 난분해성 산업폐수처리에 이용할 수 있도록 최적 화하였다.

\section{재료 및 방법}

\section{페놀계 및 알켄계 염소화합물 분해 균주의 분리}

페놀계 염소화합물인 pentachlorophenol (PCP) 분해균주 의 분리는 유기염소계화합물이 오염된 토양 및 산업폐수를 균원 시료로 하여 멸균된 증류수로 연속 희석한 후 희석액을 Luria-Bertani (LB) 평판 고체배지에 도말하여 나타난 집락을 분리용 고체 배지[12]에 접종하고 $\mathrm{PCP}$ 를 증기상태로 공급하 면서 $30^{\circ} \mathrm{C}$ 에서 3 일간 배양한 후 집락을 관찰하여 자화능이 우수한 균주를 분리하여 1 차 선별하였다. 1 차 선별된 균주는 $250 \mathrm{ml}$ Erlenmeyer flask에 PCP $500 \mathrm{mg} / 1$ 가 함유된 분리용 액체배지[12]에 접종하여 $30^{\circ} \mathrm{C}$ 에서 3 일간 배양한 후 $\mathrm{PCP}$ 분해 능이 우수한 균주를 선별하였다.

알켄계 염소화합물인 TCE 분해균주를 분리하기 위하여 유 기염소계화합물이 오염된 토양 및 산업폐수를 균원 시료로 하여 분리용 고체배지에 $\mathrm{TCE}$ 를 $200 \mathrm{uM}$ 농도로 첨가하여 $30^{\circ} \mathrm{C}$ 에서 3 일간 배양한 후 나타나는 집락을 분리하여 1 차 선별
하였다. 분리된 균주는 $5 \mathrm{ml}$ 의 액체배지를 넣은 $60 \mathrm{ml}$ head-space vial 에 유일한 탄소원 및 에너지원으로 $300 \mathrm{uM}$ 의 TCE를 포함한 배지에 접종하여 균체성장 및 TCE의 분해능 이 우수한 균주를 선별하였다. 분리용 액체배지는 고 등[12]이 사용한 배지를 사용하였으며, 배지 11 당 각 성분의 조성과 함량은 $\mathrm{NH}_{4} \mathrm{Cl} 1.0 \mathrm{~g}, \mathrm{~K}_{2} \mathrm{HPO}_{4} 4.35 \mathrm{~g}, \mathrm{NaH}_{2} \mathrm{PO}_{4} 3.9 \mathrm{~g}, \mathrm{MgSO}_{4}$. $7 \mathrm{H}_{2} \mathrm{O} 0.48 \mathrm{~g} \mathrm{CaCl}_{2} 0.03 \mathrm{~g}$, $\mathrm{FeSO}_{4} 0.01 \mathrm{~g}, \mathrm{MnCl}_{2} 0.01 \mathrm{~g}, \mathrm{CoCl}_{2}$ $0.001 \mathrm{~g}, \mathrm{Na}_{2} \mathrm{MnO}_{4} 0.001 \mathrm{~g}$ 등이며 $\mathrm{pH}$ 를 6.8 로 조절하였다.

\section{미생물 배양}

분리균주의 전 배양은 완전배지(Luria-Bertani medium) 50 $\mathrm{ml}$ 를 $250 \mathrm{ml}$ Erlenmeyer flask에 넣고 분리균주를 백금이로 접종하여 $30^{\circ} \mathrm{C}$ 에서 24 시간 배양하였다. 페놀계 염소화합물 PCP 분해균주의 배양은 PCP $500 \mathrm{mg} / 1$ 가 함유된 최소배지 [13] $50 \mathrm{ml}$ 를 $250 \mathrm{ml}$ Erlenmeyer flask에 넣은 후 전 배양액을 $2 \%(\mathrm{v} / \mathrm{v})$ 가 되게 접종하여 $\mathrm{pH} 7.0,30^{\circ} \mathrm{C}$ 에서 $150 \mathrm{rpm}$ 으로 75시간 배양하면서 배양시간 별 균체생육 및 $\mathrm{PCP}$ 의 농도를 측정하였다. 알켄계 염소화합물 TCE 분해균주의 경우 액체 최소배지 $5 \mathrm{ml}$ 를 $60 \mathrm{ml}$ head-space vial에 넣은 후 전 배양액을 $2 \%(\mathrm{v} / \mathrm{v})$ 접종 한 다음 $1 \mu \mathrm{l}$ syringe로 $\mathrm{TCE}$ 를 $300 \mathrm{uM}$ 농도로 첨가하여 접종하여 $\mathrm{pH} 7.0,30^{\circ} \mathrm{C}$ 에서 $150 \mathrm{rpm}$ 으로 75 시간 배 양하면서 배양시간 별 균체생육 및 $\mathrm{TCE}$ 의 농도를 측정하였다.

인공페수를 이용한 복합미생물제제의 처리효율 시험은 인 공페수에 $\mathrm{PCP}$ 와 $\mathrm{TCE}$ 를 각각 $500 \mathrm{mg} / 1$ 와 $300 \mathrm{uM}$ 농도로 첨가 한 후 75 시간 배양하였으며, 복합미생물제제의 농도는 200 $\mathrm{mg} / 1$ 로 조절하였다. 현장 폐수의 모델로 제조한 인공폐수는 peptone $6.0 \mathrm{~g}$, yeast extract $4.0 \mathrm{~g}$, urea $1.0 \mathrm{~g}, \mathrm{NaCl} 1.0 \mathrm{~g}$, $\mathrm{K}_{2} \mathrm{HPO}_{4} 0.1 \mathrm{~g}, \mathrm{KCl} 0.14 \mathrm{~g}, \mathrm{CaCl}_{2} 0.14 \mathrm{~g}, \mathrm{MgSO}_{4} 0.1 \mathrm{~g}$ 을 수도수 11 에 녹인 후 $\mathrm{pH} 7.0$ 으로 조정한 인공폐수를 제조하여 배양 액으로 사용하였다[10].

\section{분리균주의 동정 및 보존}

분리균주의 형태적, 생리적 그리고 생화학적 특징을 조사한 후 Bergey's manual of determinative bacteriology [18]와 Manual for the identification of medical bacteria (2nd ed.) [14]에 따라서 균주 동정을 실시하였다. 각 균주의 DNA 염기 조성 $(\mathrm{G}+\mathrm{C}$ 함량)은 Tomaoka와 Komagata [19]의 방법에 따라 reversed-phase HPLC에 의해 분석하였다. 분리균주는 최소 배지에 계대배양하여 보존하였고, 또한 ampoule에 동결 건조 하여 보관하였다.

\section{균체량 측정}

균체량은 분리균주의 배양액을 원심분리하여 얻은 균체를 증류수로 2회 세척 한 후 $105^{\circ} \mathrm{C}$ 에서 8시간 건조시킨 다음 세포 건조중량(dry cell weight)으로 측정하였다. 


\section{복합 미생물제제 제조}

복합미생물제제는 ribbon impeller가 부착된 mixer에 탈지 강을 넣고 분리균주인 $\mathrm{PCP}$ 분해균주, $\mathrm{TCE}$ 분해균주와 이미 분리된 방향족화합물 분해균주의 배양액을 각각 8 (탈지강) 2 (배양액)의 비율로 혼합하여 교반하면서 흡착시킨 후 $37^{\circ} \mathrm{C}$ 에 서 48 시간 고상 발효한 다음 상온에서 풍건하여 제조하였다. 미생물제제의 제조에 사용된 각 균주의 배양액은 미생물 생육 이 활발한 $10^{7} \sim 10^{8} \mathrm{CFU} / \mathrm{g}$ 의 배양액을 사용하였다. 분리균주 인 PCP 분해균주 Acetobacter sp. GP5, Pseudomonas sp. GP19 와 TCE 분해균주 Arthrobacter sp. GA6, Xanthomonas sp. GA15에 이미 분리된 benzene과 phenol 등 방향족화합물 분 해균주인 Acinetobacter sp. KN11 [11], Neisseria sp. GN13 [13] 의 배양액을 각각 제제화하여 제조된 제제 6종을 혼합하여 복합미생물제제를 제조하였다. 복합미생물제제에 사용된 각 미생물제제는 PCP 분해용 미생물제제 $40 \%$, TCE 분해용 미생 물제제 $40 \%$, 방향족화합물 분해용 미생물제제 $20 \%$ 의 비율로 혼합하여 제제화 하였다.

\section{분해능 측정}

$\mathrm{PCP}$ 와 $\mathrm{TCE}$ 의 정량은 $\mathrm{HP}-\mathrm{VOC}$ capillary column $(90 \mathrm{~m} \times$ $530 \mu \mathrm{m} \times 3.0 \mu \mathrm{m})$ 을 장착한 gas chromatograph $(\mathrm{HP} 6890 \mathrm{~N}$, Hewlett Packard)로 분석하였다. 분석 시 column의 온도는 $80^{\circ} \mathrm{C}$ 였으며, injector와 detector의 온도는 각각 $230^{\circ} \mathrm{C}$ 와 $250^{\circ} \mathrm{C}$ 였다. 운반기체 $\left(\mathrm{N}_{2}\right)$ 의 유속은 $30 \mathrm{ml} / \mathrm{min}$ 로 유지하였으며, 시 료의 주입량은 $1.0 \mu \mathrm{l}$ 였다.

\section{유기염소계 산업폐수의 처리효율 분석}

난분해성 유기염소계 산업폐수의 처리효율을 조사하기 위 한 연속배양 실험은 아크릴로 제작된 실험실 규모의 반응조 [18]을 이용하여 조사하였다. 유기염소계 산업폐수처리 시험 을 위한 반응조는 활성오니공정과 접촉산화식공정을 병행하 여 운전할 수 있도록 설계하였다. 실험실 규모의 장치는 용량 수도수 21 의 투명 아크릴판을 이용하여 제작하였으며, 공기는 반응조의 바닥에 산기석을 설치하고 air blower를 조절하여 $2 \sim 3 \mathrm{mg} / \mathrm{l}$, 온도는 자동조절기를 이용하여 $25 \pm 2^{\circ} \mathrm{C}$, 그리고 수 리학적 체류시간(HRT)은 24시간으로 유지하였으며 $\mathrm{pH}$ 는 7.0 으로 조절하였다.

대상폐수의 처리효율 분석을 위한 $\mathrm{COD}_{\mathrm{Mn}}$ (chemical oxygen demand), TOC (total organic carbon)와 MLSS (mixed liquor suspended solid)의 농도측정은 standard method [2] 에 준하여 분석하였으며, 용존 TOC 농도는 시료를 12,000 rpm으로 원심분리 한 후 상등액을 Whatman membrane filter $(0.45 \mu \mathrm{m})$ 를 이용하여 cell을 완전히 제거시킨 후 TOC 분 석기 (TOC-V CPH, Shimazu)로 분석하였다. TOC는 $\mathrm{TC}$ (total carbon)에서 IC (inorganic carbon)를 제외한 값으로 산 출하였다.

\section{결과 및 고찰}

\section{페놀계 염소화합물 PCP 및 알켄계 염소화합물 TCE 분해 균주의 분리}

페놀계 염소화합물인 $\mathrm{PCP}$ 분해 균주의 분리는 전국 각지에 서 채집한 산업폐수 및 산업폐기물 오염지역과 토양을 균원 시료로 하여 $\mathrm{PCP}$ 를 유일 탄소원으로 첨가한 최소 고체배지를 이용하여 이중 $\mathrm{PCP}$ 의 분해 활성이 우수한 균주를 선별하였다. 1 차 선별은 PCP $500 \mathrm{mg} / 1$ 를 증기상으로 공급하면서 $30^{\circ} \mathrm{C}$ 에 서 3일간 고체배양 하였을 때 집락 형성능이 뛰어난 25 균주를 선별하였다. 이들 균주 중 $\mathrm{PCP}$ 을 공급한 액체 최소배지에서 $\mathrm{PCP}$ 의 분해능 및 생육정도를 비교한 결과, 분리균주 $\mathrm{GP5}$ 와 $\mathrm{GP} 19$ 는 $68 \%$ 와 $71 \%$ 의 $\mathrm{PCP}$ 분해능을 나타내어 가장 높은 분해 효율을 보였으며, 이때 GP5와 GP19의 균체생육은 각각 0.685 $\mathrm{g} / 1$ 과 $0.712 \mathrm{~g} / 1$ 을 나타내었다. 따라서PCP 분해능과 균체생육 이 가장 우수한 균주인 GP5와 GP19를 최종 선별하여 실험에 이용하였다.

알켄계 염소화합물 TCE 분해균주는 전국 각지의 오염지역 토양 및 폐수를 균원 시료로 하여 알켄계 염소화합물인 TCE를 유일한 탄소원 및 에너지원으로 하여 배양한 후 나타난 14 개 의 집락을 순수 분리하였다. 순수 분리된 균주를 Teflon septa 가 부착된 $60 \mathrm{ml}$ head-space vial에 최소배지 $5 \mathrm{ml}$ 넣은 다음 $\mathrm{TCE}$ 를 $300 \mathrm{uM}$ 을 넣고 배양하여 TCE의 분해능과 균체 생육이 가장 우수한 균주인 GA6 (TCE 분해능 $75 \%$, 균체생육 0.702 $\mathrm{g} / 1$ )와 GA15 (TCE 분해능 $77 \%$, 균체생육 $0.725 \mathrm{~g} / 1$ )를 최종 선별하여 본 연구에 사용하였다.

\section{분리균주의 동정}

분리 균주의 동정을 위하여 형태학적, 생리학적, 생화학적 특성을 조사하였다(data not shown). 페놀계 염소화합물PCP 분해균주인 분리균주 $\mathrm{GP5}$ 의 고체배지 에서의 특성은 $\mathrm{GYC}$ 배지(glucose $5 \%$, yeast extract $1 \%, \mathrm{CaCO}_{3} 3 \%$ )에서 생육이 좋았으며, 이들 배지에서의 집락은 반투명한 흰색을 띄었다. 분리균주 GP5의 형태학적 생리학적 특징은 Gram 음성 간균 으로서 Catalase를 생성하였으며 nitrate reduction test에서 는 음성을 나타내었다. 또한 propanol, butanol, mannose, glucose에서 산을 생성하였으며, DNA 염기성분인 $\mathrm{G}+\mathrm{C}$ 함량은 $57.2 \%$ 를 나타내어 Acetobacter sp. 세균과 유사한 특징을 나타 내었다. 그리고 분리균주 GP19는 Gram 음성의 간균으로서 포자를 형성하지 못하였으며, 운동성을 나타내었다. Oxidase test에서 양성반응을 보였으며 mannose, galactose, fructose 에서 산을 생성하였다. Starch를 잘 분해하지 못하였으며 gelatin을 잘 분해하였다. DNA의 $\mathrm{G}+\mathrm{C}$ 함량은 $60.6 \%$ 를 나타내 었으며, 이러한 결과는 Pseudomonas sp. 과 유사한 특징을 나 타내었다.

알켄계 염소화합물 $\mathrm{TCE}$ 분해균주인 분리균주 GA6는 
Gram 양성의 간균으로서 포자를 형성하지 못하였으며, 절대 호기성균으로서 생육 최적온도는 $25 \sim 30^{\circ} \mathrm{C}$ 였다. Starch와 casein을 잘 분해하였고 glucose로부터 산을 생성하지 못하였 으며, DNA 염기성분인 $\mathrm{G}+\mathrm{C}$ 함량은 $62.9 \%$ 였다. 이러한 특징 은 Arthrobacter sp. 세균과 유사한 것으로 나타났다. 또한 분리 균주 GA15는 Gram 음성 간균으로서 세포의 크기는 $0.4 \sim 0.6 \times 0.8 \sim 1.7 \mu \mathrm{m}$ 이며 운동성을 나타내었다. Catalase를 생성하였으며, nitrate reduction, indole production, Voges-Proskauer test에서는 음성을 나타내었다. Gelatin과 starch를 잘 분해하지 못하였고, esculin은 잘 분해하였다. Glucose와 mannose에서 산을 생성하였으며, DNA 염기성 분인 G+C 함량은 $67.5 \%$ 로 나타나 Xanthomonas sp.과 유사한 특징을 보여주었다. 이러한 결과를 바탕으로 PCP 분해균주 GP5와 GP19는 Acetobacter sp., Pseudomonas sp. 과 유사한 것 으로 나타났으며, TCE 분해균주 GA6와 GA15는 Arthrobacter sp., Xanthomonas sp.과 유사한 것으로 나타나 최종적으로 Acetobacter sp. GP5, Pseudomonas sp. GP19, Arthrobacter sp. GA6, Xanthomonas sp. GA15로 명명하였다.

\section{난분해성 산업폐수처리를 위한 복합미생물제제 제조}

분리균주를 페놀계 염소화합물과 알켄계 염소화합물이 포 함된 난분해성 산업폐수 처리용 미생물제제로 개발하기 위하 여, 탈지강을 담체로 사용하였다. 복합미생물제제는 탈지강에 $\mathrm{PCP}$ 분해균주인 분리균주 Acetobacter sp. GP5, Pseudomonas sp. GP19와 TCE 분해균주인 분리균주 Arthrobacter sp. GA6 Xanthomonas sp. GA15의 배양액과 함께, 이미 분리된 방향족 화합물 분해균주 Acinetobacter sp. KN11 [11]과 Neisseria sp. GN13 [13]의 배양액을 첨가하여 제조하였다. 난분해성 산업 폐수 처리용 균주로 선별된 각각의 균주를 회분식 액체배양에 서 균체 생육을 위한 최적 배지조성을 확립하였으며, 각 균체 배양액을 탈지강에 2:8 비율로 혼합한 후 2일 동안 고상 발효한 다음 상온에서 풍건하여 6종의 균주로 각각 미생물제 제를 만든 다음 6 종의 제제를 혼합하여 복합미생물제제를 제 조한 결과 Table 1과 같은 미생물제제의 특성을 나타내었다. 미생물제제에 포함된 6 종의 균주 모두 $10^{8} \mathrm{CFU} / \mathrm{g}$ 이상의 높
은 균체량을 유지하고 있었으며, 수분함량은 $25 ~ 29 \%$ 를 유지 하였고, 6 종의 제제가 혼합된 복합미생물제제 OC17의 경우 $2.8 \times 10^{9} \mathrm{CFU} / \mathrm{g}$ 의 균체수를 갖고 있으며, 밀도는 $0.299 \mathrm{~g} / \mathrm{cm}^{3}$, 수분함량은 $26.8 \%$ 를 나타내었다. 염소화합물이 포함되어있는 난분해성 폐수의 처리는 일반 균주로는 효과를 거두기 어렵기 때문에 이들 물질의 분해균주를 분리하여 배양한 후 미생물을 제제화 또는 고정화하여 접종함으로서 개체군의 밀도를 높여 생분해를 효과를 기할 수 있다[8]. 따라서 염소화화합물에 분 해력이 높은 균주 들을 이용하여 난분해성 유기염소계 산업폐 수에 특이적으로 사용할 수 있는 복합 미생물제제 OC17를 제조하였다.

\section{복합 미생물제제 OC17의 PCP와 TCE 분해효과}

난분해성인 염소화 화합물이 포함된 폐수의 효과적인 처리 를 위하여 선별된 균주로 구성된 복합미생물제제 OC17을 이 용하여 인공폐수상에 각각 포함 되어있는 $\mathrm{PCP}$ 와 TCE의 분해 효율을 최적화하기 위하여 플라스크 수준에서 배양조건과 배 양시간에 따른 영향을 조사하였다. 복합미생물제제 OC17에 의한 $\mathrm{PCP}$ 와 TCE분해능과 균체생육에 미치는 온도와 $\mathrm{pH}$ 의 영향을 조사한 결과(data not shown), 온도변화에 따른 PCP 감소효과는 처리온도 $30^{\circ} \mathrm{C}$ 에서 $82 \%$ 로 가장 높은 분해효율을 나타내었으며, $\mathrm{TCE}$ 의 경우 처리온도 $25^{\circ} \mathrm{C}$ 에서 $87 \%$ 로 가장 높은 분해효율을 나타내었다.

$\mathrm{PCP}$ 와 $\mathrm{TCE}$ 의 분해능과 균체생육에 미치는 $\mathrm{pH}$ 의 영향을 조사하기 위하여 인공폐수의 초기 $\mathrm{pH}$ 를 4.0 에서 9.0 으로 각각 조절하여 배양한 결과, $\mathrm{PCP}$ 는 $\mathrm{pH} 7.5$ 에서 $85 \%$ 의 분해율을 나타내어 가장 잘 분해되었으며 $\mathrm{TCE}$ 의 경우 $\mathrm{pH}$ 7.0에서 $89 \%$ 로 분해능이 최대에 달했다. 이때 $\mathrm{PCP}$ 와 $\mathrm{TCE}$ 가 포함된 인공 폐수의 처리 온도는 각각 $30^{\circ} \mathrm{C}$ 와 $25^{\circ} \mathrm{C}$ 로 조절하였다. 복합 미 생물제제 $\mathrm{OC} 17$ 은 $\mathrm{pH}$ 6.0과 8.0의 사이의 넓은 범위에서도 높은 분해율과 균체증식을 나타내었으며 이러한 결과는 실제 산업폐수가 $\mathrm{pH} 5.0$ 에서 $\mathrm{pH} 8.0$ 사이에 있음을 고려할 때 현장 에서 별도의 $\mathrm{pH}$ 조절 없이 복합미생물제제 OC17을 사용할 수 있을 것으로 생각된다.

배양시간에 따른 $\mathrm{PCP}$ 의 분해력 시험은 배양 65시간에서

Table 1. Characteristics of microbial augmentations for the treatment of industrial wastewater containing chlorinated organic compounds

\begin{tabular}{lcccc}
\hline \multicolumn{1}{c}{ Strains } & $\begin{array}{c}\text { Total viable count } \\
(\mathrm{CFU} / \mathrm{g})\end{array}$ & $\begin{array}{c}\text { Bulk density } \\
\left(\mathrm{g} / \mathrm{cm}^{3}\right)\end{array}$ & $\begin{array}{c}\text { Water content } \\
(\%)\end{array}$ & $\begin{array}{c}\text { Particle size } \\
(\mathrm{mesh})\end{array}$ \\
\hline Acetobacter sp. GP5 & $3.7 \times 10^{9}$ & 0.282 & 26.7 & $50 \sim 100$ \\
Pseudomonas sp. GP19 & $5.2 \times 10^{9}$ & 0.302 & 25.9 & $50 \sim 100$ \\
Arthrobacter sp. GA6 & $7.4 \times 10^{8}$ & 0.305 & 29.2 & $50 \sim 100$ \\
Xanthomonas sp. GA15 & $1.6 \times 10^{9}$ & 0.300 & 27.4 & $50 \sim 100$ \\
Acinetobacter sp. KN11 & $2.3 \times 10^{10}$ & 0.298 & 26.7 & $50 \sim 100$ \\
Neisseria sp. GN13 & $3.9 \times 10^{8}$ & 0.301 & 25.4 & $50 \sim 100$ \\
Microbial augmentation OC17 & $2.8 \times 10^{9}$ & 0.299 & 26.8 & $50 \sim 100$ \\
\hline
\end{tabular}




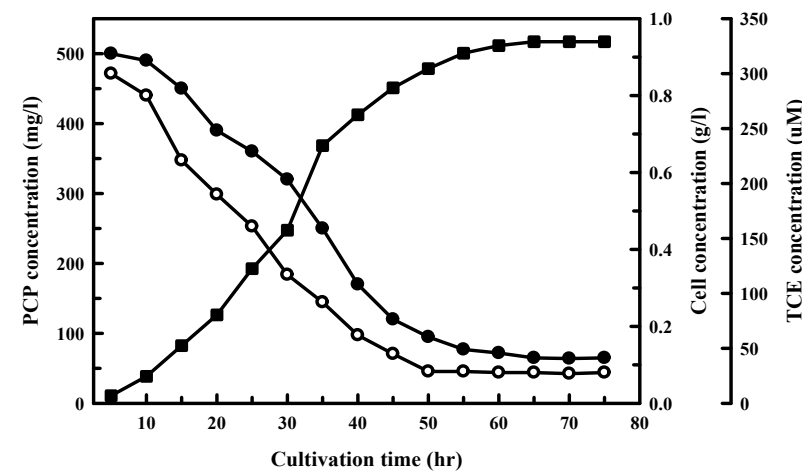

Fig. 1. Time course of PCP and TCE degradation by microbial augmentation OC17. The symbols ; $\mathbf{O}$ : PCP concentration, $\mathrm{O}$ : TCE concentration, $\mathbf{\square}$ : cell concentration.

감소율 $87 \%$ 로 최대에 이르렀고 $\mathrm{TCE}$ 의 경우 배양 50 시간에 $90 \%$ 의 분해효율을 나타내었다(Fig. 1). 이상의 결과에서와 같 이 $\mathrm{PCP}$ 분해균주, $\mathrm{TCE}$ 분해균주와 방향족 화합물 분해균주로 구성되어 있는 복합미생물제제 $\mathrm{OC} 17$ 은 $\mathrm{PCP}$ 와 TCE 에서 높 은 분해능을 나타내어, 염소화화합물을 함유한 석유화학폐수 등의 폐수처리 시 발생하는 다양한 온도와 $\mathrm{pH}$ 변화에도 효과 적으로 처리할 수 있는 적합한 제제로 사용될 수 있을 것으로 생각된다.

\section{$\mathrm{PCP}$ 및 TCE 농도의 영향}

유기염소화합물 $\mathrm{PCP}$ 와 $\mathrm{TCE}$ 가 각각 포함되어있는 인공폐 수상에서 $\mathrm{PCP}$ 와 $\mathrm{TCE}$ 의 농도에 따른 복합미생물제제 $\mathrm{OC} 17$ 의 분해능 및 균체성장을 조사하기 위하여, $\mathrm{PCP}$ 는 인공폐수상 에 $300 \mathrm{mg} / 1$ 에서 $2,500 \mathrm{mg} / 1$ 의 농도로 첨가하였으며, $\mathrm{TCE}$ 의 경우 $200 \mathrm{uM}$ 에서 $3 \mathrm{mM}$ 농도로 첨가하여 조사하였다. 폐놀계 화합물 $\mathrm{PCP}$ 는 $500 \mathrm{mg} / \mathrm{l}$ 이하의 농도에서는 배양 60 시간 이후 에 $85 \%$ 이상 분해되었으며 $1,000 \mathrm{mg} / 1$ 에서는 배양 80 시간에 $70 \%$ 분해되었고, $2,000 \mathrm{mg} / 1$ 이상의 고농도에서는 $30 \%$ 이하 의 낮은 분해활성을 나타내었다(Fig. 2). Colores 등[5]은 Sphingomonas sp.의 경우 액체배지에서 PCP $500 \mathrm{mg} / 1$ 를 분해 할 수 있다고 보고하였으나, 본 연구결과에서는 $1,000 \mathrm{mg} / \mathrm{l}$ 의 고농도에서도 높은 분해활성을 나타내었다. 알켄계 염소화합 물 TCE 농도별 분해효과를 나타낸 결과 Fig. 3과 같이 TCE $3 \mathrm{mM}$ 이 첨가된 고 농도에서는 $23 \%$ 의 낮은 분해율을 나타내 었으나 $500 \mathrm{uM}$ 이하의 농도에서는 $85 \%$ 이상 분해되었으며, $1 \mathrm{mM}$ 의 고농도에서도 $74 \%$ 의 높은 분해율을 나타내었다. 유 기염소계 산업폐수 처리용 제제로 개발된 복합미생물제제 OC17을 이용한 인공폐수처리에서 페놀계 염소화합물 PCP 와 알켄계 염소화합물 TCE모두에 나타난 높은 분해활성은 실제 폐수처리 현장에서 다양한 성상의 각종 염소화 화합물이 포함되어 있는 석유화학폐수 등 난분해성 산업폐수의 처리에 복합미생물제제 OC17은 효과적인 제제로 사용될 수 있을 것 으로 생각된다.

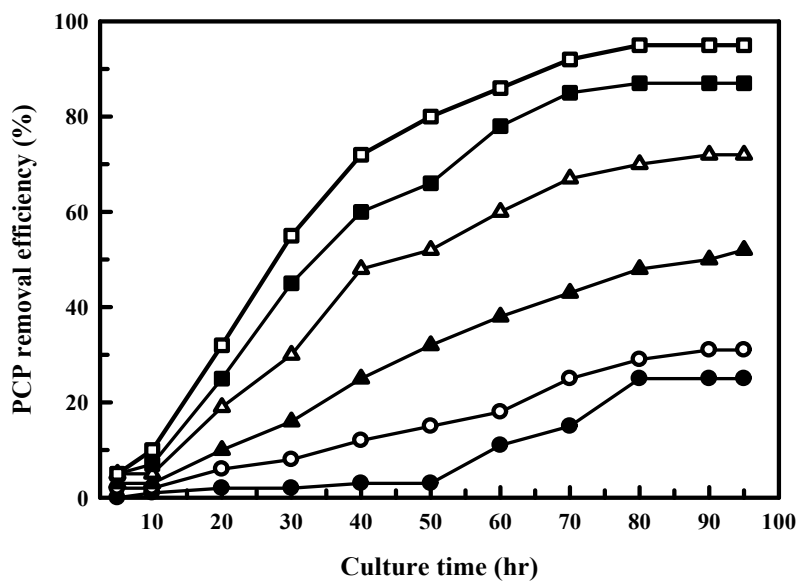

Fig. 2. Effect of PCP concentration on the degradation of PCP in the treatment of artificial wastewater by microbial augmentation OC17. The symbols ; $0: 300 \mathrm{mg} / \mathrm{l}, \mathrm{O}$ : $500 \mathrm{mg} / \mathrm{l}, \mathbf{\square}: 1,000 \mathrm{mg} / \mathrm{l}, \square: 1,500 \mathrm{mg} / \mathrm{l}, \mathbf{\Delta}: 2,000$ $\mathrm{mg} / \mathrm{l}, \triangle: 2,500 \mathrm{mg} / \mathrm{l}$.

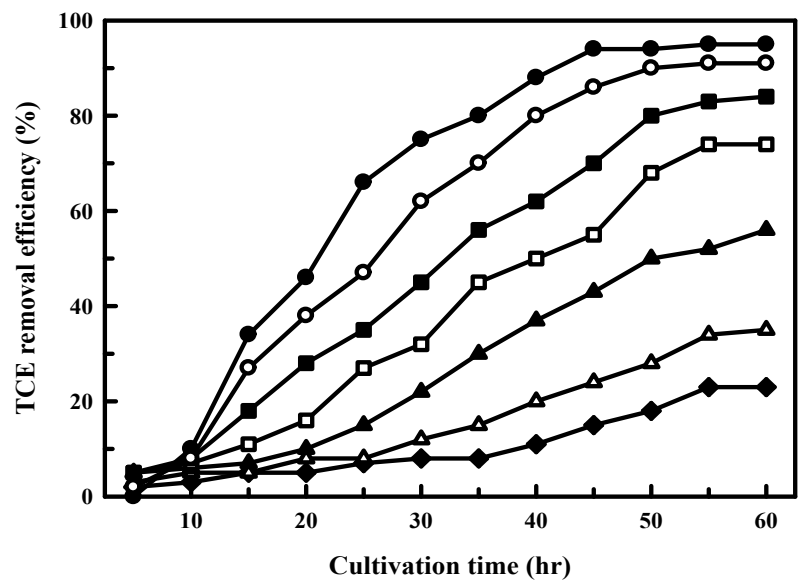

Fig. 3. Effect of TCE concentration on the degradation of TCE in the treatment of artificial wastewater by microbial augmentation OC17. The symbols ; : $200 \mathrm{uM} \mathrm{,} \bigcirc: 300$ $\mathrm{uM}, \mathbf{\square}: 500 \mathrm{uM}, \square: 1 \mathrm{mM}, \boldsymbol{\Delta}: 1.5 \mathrm{mM}, \triangle: 2 \mathrm{mM}$, $\diamond: 3 \mathrm{mM}$.

\section{유기염소계 산업폐수 처리 시 복합미생물제제 OC17농도} 의 영향

유기염소계 산업폐수 처리를 위한 염소화화합물 분해 미생 물제제인 $\mathrm{OC} 17$ 의 적정 투입량을 검토하기 위하여 투여농도 를 달리하여 화학적 산소요구량(COD)의 감소효율을 측정하 여 플라스크 수준에서의 처리 효과를 검토하였다. 복합미생물 제제 OC17의 초기 투입농도를 각각 $100 \mathrm{mg} / 1$ 에서 600 $\mathrm{mg} / 1$ 로 투입한 결과 Fig. 4와 같이 초기 투입농도 $200 \mathrm{mg} / 1$ 에서 $400 \mathrm{mg} / 1$ 의 범위에서 높은 $\mathrm{COD}$ 감소율을 나타내었으 며, 복합미생물제제 OC17을 $300 \mathrm{mg} / \mathrm{l}$ 을 투입하였을 때 $86 \%$ 로 가장 높은 $\mathrm{COD}$ 감소율을 나타내어 유기염소계 산업폐수 를 효과적으로 처리하는 것으로 나타났다. 복합미생물제제 


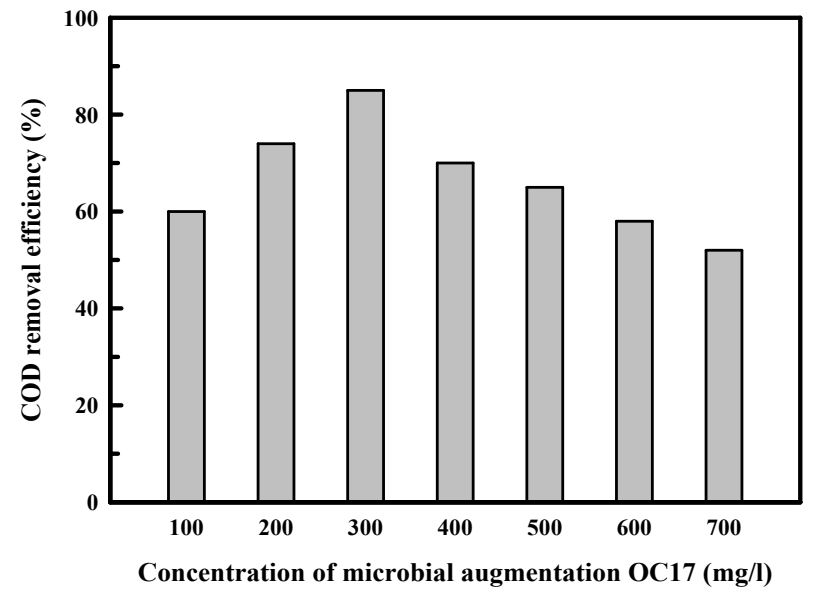

Fig. 4. Effect of microbial augmentation OC17 concentration on the removal efficiency of COD in industrial wastewater containing chlorinated organic compounds. The symbols ; : microbial augmentation OC17.

OC17을 $500 \mathrm{mg} / 1$ 이상 투입하였을 때 처리효율이 떨어지는 것으로 확인되었다. 이는 복합미생물제제 OC17의 담체로 사 용된 탈지강의 과다사용으로 인하여 유기물의 농도가 일부 용존되어 나왔을 가능성을 배제할 수 없으며, 과다한 미생물 제제 사용이 오히려 처리효율을 낮게 하는 요인으로 적용될 수 있음을 보여주고 있다. 이와 같은 결과로 유기염소계 산업 폐수처리 시 초기 접종량은 $300 \mathrm{mg} / 1$ 로 조절하여 사용하였 다.

\section{$\mathrm{pH}$ 및 온도의 영향}

유기염소계 산업폐수의 생물학적 처리에서 $\mathrm{pH}$ 및 온도는 미생물의 생육에 큰 영향을 미친다. 따라서 유기염소계 산업 폐수 상에서의 다양한 $\mathrm{pH}$ 와 온도변화에 따른 $\mathrm{COD}$ 감소효율 을 측정하여 복합미생물제제 OC17의 산업폐수 처리효율을 조사하였다. 유기염소계 산업폐수의 $\mathrm{pH}$ 를 4.0 에서 10.0 으로 조절하여 복합 미생물 제제 OC17과 유기염소계 산업폐수처 리장의 폭기조 활성슬러지를 처리한 결과 Fig. 5와 같다.

복합미생물제제 $\mathrm{OC} 17$ 을 처리한 처리구에서는 $\mathrm{pH}$ 7.5에서 $84 \%$ 의 $\mathrm{COD}$ 감소율을 나타내어 가장 높은 처리효율을 나타내 었으며 $\mathrm{pH}$ 5와 10사이의 넓은 범위에서 안정적인 처리효율을 나타내었다. 이는 복합미생물제제 $\mathrm{OC} 17$ 을 이용한 $\mathrm{PCP}$ 와 $\mathrm{TCE}$ 의 처리효율 시험에서 나타난 최적 $\mathrm{pH}$ 조건과 유사한 결 과를 나타내었다. 반면 기존 폭기조 활성슬러지를 이용한 대 조구의 경우 $\mathrm{pH} 5$ 이하와 $\mathrm{pH}$ 8.5이상의 $\mathrm{pH}$ 에서는 처리효율 이 급격히 떨어져 $\mathrm{pH}$ 변화에 따른 활성슬러지 미생물의 활성 이 현저히 저하되는 것으로 나타났다. 복합미생물제제 OC17 처리구와 활성슬러지 처리구 모두 $\mathrm{pH} 7.0$ 부근의 중성 영역에 서 가장 높은 처리효율을 나타내어 폭기조의 운전관리 시 중 성 영역에서 호기성 세균의 생육활성과 유기물 제거효과가

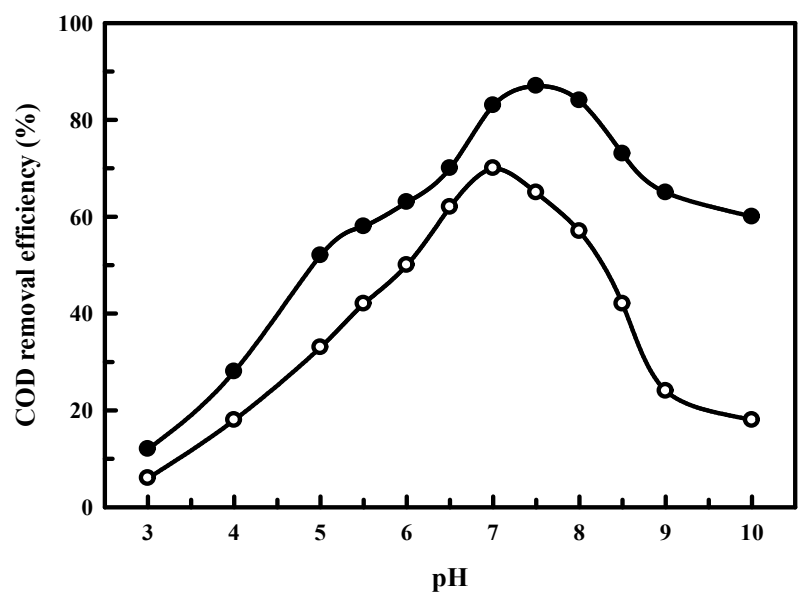

Fig. 5. Effect of $\mathrm{pH}$ on the removal efficiency of COD in industrial wastewater containing chlorinated organic compounds. The symbols; : microbial augmentation OC17, $\bigcirc$ : activated sludge.

가장 크게 나타난다는 보고[20]와 일치하였으며, 복합미생물 제제 $\mathrm{OC} 17$ 의 경우 비교적 넓은 범위의 $\mathrm{pH}$ 영역에서 유기염소 계 산업폐수를 안정적으로 처리하는 것으로 나타났다.

복합미생물제제 OC17과 활성슬러지의 온도변화에 따른 유 기염소계 산업폐수 의 처리효율을 조사하기 위하여 $15^{\circ} \mathrm{C}$ 부터 $40^{\circ} \mathrm{C}$ 까지 조사한 결과(data not shown), 복합미생물제제 $\mathrm{OC} 17$ 의 경 우 $25^{\circ} \mathrm{C}$ 에서 가장 높은 $\mathrm{COD}$ 감소율을 나타내었으 며 $20^{\circ} \mathrm{C}$ 와 $35^{\circ} \mathrm{C}$ 사이의 온도에서도 $80 \%$ 이상의 높은 처리효율 을 나타내었다. 복합미생물제제 OC17를 이용한 유기염소계 산업폐수처리의 최적 처리온도는 인공폐수에서 $\mathrm{PCP}$ 와 $\mathrm{TCE}$ 최적처리 온도와 유사한 결과를 나타내었다. 이러한 결과는 여러 종류의 유기염소계 화합물이 포함되어있는 실제 산업폐 수처리에서 복합미생물제제 OC17은 효율적인 $\mathrm{pH}$ 와 온도 조절이 가능한 유용한 제제로 사용이 가능한 것으로 생각된 다. 활성슬러지만으로 처리한 대조구의 경우 $25^{\circ} \mathrm{C}$ 와 $35^{\circ} \mathrm{C}$ 처 리온도에서 $58 \sim 67 \%$ 의 $\mathrm{COD}$ 제거율을 나타내어 비교적 활발 한 분해율을 나타내었으나, $20^{\circ} \mathrm{C}$ 이하의 저온에서는 급격히 처리효율이 떨어지는 것으로 나타났다. 유기염소계 산업폐수 처리시 온도는 미생물의 생육에 영향을 미치는 환경인자로서 미생물의 호흡과 대사기능의 활성에 상당한 요인으로 작용한 다. 특히 활성슬러지 폭기조의 온도는 일반적으로 기상변화에 의존하며 폭기조의 위치에 따라 계절별로 상당한 차이를 나타 내고 있으며, 대부분 활성오니상의 중온균의 활성에 의존하는 폭기조의 처리효율은 특히 동절기에 급격히 떨어진다[20]. 이 상의 결과에서 유기염소계 산업폐수처리용 복합미생물제제 $\mathrm{OC} 17$ 은 $20^{\circ} \mathrm{C}$ 이하의 저온에서도 $62 \sim 70 \%$ 의 높은 $\mathrm{COD}$ 제거 효율을 나타내어 저온에서의 활성이 우수한 것으로 나타나 특히 동절기 시 유기염소계 산업폐수의 처리효율을 높이는데 크게 기여할 것으로 생각된다. 


\section{연속배양에 의한 유기염소계 산업폐수의 처리}

아크릴로 제작된 실험실 규모의 반응조[18]를 이용하여 연 속배양을 통한 유기염소계 산업폐수의 처리효율 시험을 실시 하였다. 연속처리용 반응조에 21 의 유기염소계 산업폐수를 채우고, 모든 반응조는 유기염소계 산업폐수의 활성슬러지를 첨가하여 10 일 동안 연속배양을 통하여 시험하였다. 처리온 도와 $\mathrm{pH}$ 는 복합미생물제제 OC17의 유기염소계 산업폐수상 의 최적조건인 $25^{\circ} \mathrm{C}$ 와 7.5 로 조절하였고 복합미생물제제 OC17의 초기 접종량은 최적 처리농도인 $300 \mathrm{mg} / \mathrm{l}$ 를 투여하 였으며 안정화 기간 동안 매일 $150 \mathrm{mg} / \mathrm{l}$, 안정화 이후 70 $\mathrm{mg} / \mathrm{l}$ 를 투여하였다. 유기염소계 산업폐수의 $\mathrm{COD}_{\mathrm{MN}}$ 값은 $4,037 \mathrm{mg} / \mathrm{l}$, TOC은 4,574 mg/l, MLSS 농도는 2,346 mg/l를 나타내었다.

유기염소계 산업폐수의 체류시간은 24시간으로 초기 조정 하여 복합미생물제제 OC17의 처리구와 활성슬러지만을 첨가 한 대조구의 처리효율의 경시적인 변화를 관찰하였다(Fig. 6). 유기염소계 폐수의 연속실험에서 활성슬러지만을 처리한 대 조구의 경우 배양 7 일째 $\mathrm{COD}$ 농도는 $1,300 \mathrm{mg} / 1$ 로 약 $70 \%$ 의 $\mathrm{COD}$ 감소율을 나타내었으며, TOC의 변화는 배양 10 일째 $1,420 \mathrm{mg} / 1$ 를 나타내어 $69 \%$ 의 감소율을 나타내었다. 이때 처 리기간 동안의 MLSS 농도는 1,657 2,679 mg/1의 범위를 나타 내었다. 유기염소계 산업폐수의 활성슬러지가 포함되어있는 반응조에 복합미생물제제 OC17을 투여한 처리구에서는 배양 4 일째 $\mathrm{COD}$ 농도 $876 \mathrm{mg} / \mathrm{l}$ 를 나타내어 $79 \%$ 의 $\mathrm{COD}$ 감소율을 나타내었으며, 배양을 완료한 10일째 $91 \%$ (363 mg/l)의 높은 $\mathrm{COD}$ 감소율을 나타내어 대조구에 비하여 $20 \%$ 이상의 높은

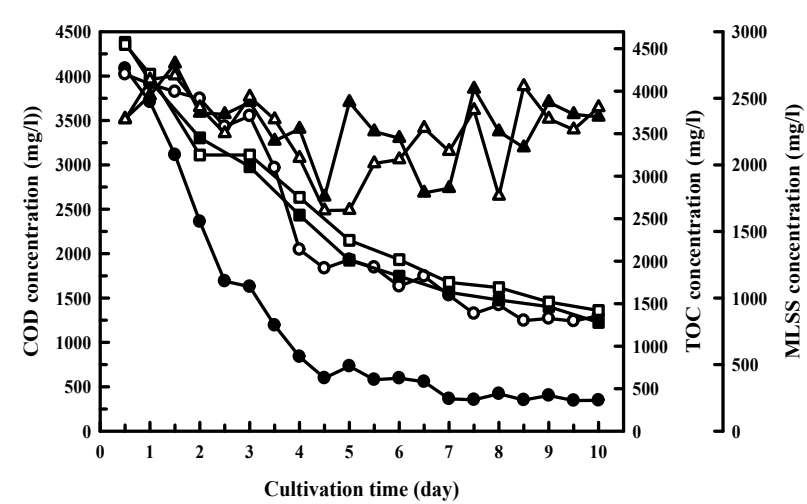

Fig. 6. Continuous culture using bench scale pilot for the biological treatment of industrial wastewater containing chlorinated organic compounds. Treatment of industrial wastewater containing chlorinated organic compounds was done at $25^{\circ} \mathrm{C}, \mathrm{pH} 7.5$ for 10 days on bench scale pilot. The symbols; : microbial augmentation OC17 (COD), $\bigcirc$ : activated sludge (COD), $\mathbf{\square}$ : microbial augmentation OC17 (TOC), $\square$ : activated sludge (TOC), : microbial augmentation OC17 (MLSS), $\triangle$ : activated sludge (MLSS).
처리효율을 나타내었다. TOC는 배양 10 일째 $72 \%$ 의 제거율을 나타내어 활성슬러지만을 처리한 대조구와 비슷한 제거율을 보였으며, 복합미생물제제 OC17의 처리기간 동안의 MLSS 농 도는 1,790 2,745 mg/1범위로서 대조구에 비하여 높은 농도를 나타내었다. 이는 복합미생물제제 OC17에 들어있는 6종의 분 리균주로 인하여 미생물개체군 증가와 미생물증식으로 인하 여 MLSS 농도가 높아진 것으로 생각된다.

이상의 결과에서와 같이 페놀계 염소화합물과 알켄계 염소 화합물 등 유기염소계 산업폐수처리용으로 개발된 복합미생 물제제 $\mathrm{OC} 17$ 은 유기염소계 산업폐수를 효과적으로 처리할 수 있는 제제로서 향후 폐수처리 현장적응 등을 통하여 $\mathrm{PCP}$ 와 $\mathrm{TCE}$ 등 난분해성 유기염소계화합물이 포함되어 있는 산업폐 수의 생물학적처리에 효과적으로 이용할 수 있을 것으로 생각 된다.

\section{감사의 글}

본 연구는 2012년 국립경남과학기술대학교 기성회의 연구 비 지원을 받아 수행되었습니다.

\section{References}

1. Apajalahti, J. H. A. and Salkinoja-Salonen, M. S. 1986. Degradation of polychlorinated phenols by Rhodococcus chlorophenolicus. Appl Microbiol Biotechnol 25, 62-67.

2. APHA, AWWA, and WEF. 1992. Standard methods for the examination of water and wastewater. 18th eds., APHA, Washington.

3. Arciero, D., Vannelli, T., Logan, M. and Hoper, A. B. 1989. Degradation of trichloroethylene by the ammonia-oxidizing bacterium Nitrosomonas europaea. Biochem Biophys Res Commun 159, 640-643.

4. Babrock, R. W. Jr., Ro, K. S., Hsieh, C. C. and Stenstorm, M. K. 1992. Development of an off-line enricher-reactor process for activated sludge degradation of hazardous wastes. Water Environ Res 64, 782-791.

5. Colores, G. M., Radehaus, P. M. and Schmit, S. K. 1995. Use of a pentachlorophenol degrading bacterium to bioremediate highly contaminated soil. Appl Biochem Biotechnol 54, 271-275.

6. Dispirito, A. A., Gulledge, J., Schiemke, A. K., Murrell, J. C., Lidstrom, M. E. and Drema, C. L. 1992. Trichloroethylene oxidation by the membrabe-associated methane monoxigenase in type I, type $I I$ and type $X$ methanotrophs. Biodegradation 2, 151-164.

7. Folsom, R. B., Chapman, P. J. and Pritchard, P. H. 1990. Phenol and trichloroethylene degradation. Pseudomonas cepacia G4 : kinetics and interaction between substrates. Appl Environ Mirobiol 56, 1279-1285.

8. Häggblom, M. M., Nohyjek, L. J. and Salkinoja-Salonen, M. S. 1988. Degradation o-methlation of chlorinated phenolic compounds by Rhodococcus and Mycobacterium strains. Appl 
Environ Microbiol 54, 3040-3052.

9. Harker, R. A. and Kim, Y. 1990. Trichloroethylene degradation by two independent aromatic-degrading pathway in Alcaligenes eutrophus JMP 134. Appl Environ Microbiol 56, 3155-3161.

10. Japanese Sewage Works Association. 1984. Methods for Sewage Analysis Japanese Sewage Works Association. Tokyo. Japan.

11. Kang, D. O. and Suh, H. H. 2011. Isolation of microorganisms and development of microbial augmentation for treatment of paper mill wastewater. J Life Sci 21, 554-560.

12. Ko, Y. H., Ha, I. H. and Bae, K. S. 1988. Isolation and characterization of a naphthalene degrading strain, Pseudomonas putida N3. Korean J Appl Microbiol Biotechnol 16, 199-204.

13. Lee, H. D., Lee, M. E., Kim, H. G. and Suh, H. H. 2013. Isolation of a phenol-degrading bacterial strain and biological treatment of wastewater containing phenols. J Life Sci 23, 1273-1279.

14. MacFaddin, J. F. 1984. Biochemical tests for identification for medical bacteria. 2nd eds,. Williams \& Wilkins Co., Baltimore, Maryland.

15. Mu, D. Y. and Scow, K. M. 1994. Effect of trichloroethylene
(TCE) and toluene concentrations on TCE and toluene biodegradation and the population density of TCE and toluene degraders in soil. Appl Environ Microbiol 60, 2661-2665.

16. Neilson, A. H., Lindgren, C., Hynning, P. A. and Remberger, M. 1988. Methylation of halogenated phenols and thiophenols by cell extracts of Gram-positive and Gram-negative bacteria. Appl Environ Microbiol 54, 524-530.

17. Oldenhuis, R., Vink, R. L., Janssen, J. M. D. B. and Witholt, B. 1989. Degradation of chlorinated aliphatic hydrocarbons by Methylosinus trichosporium OB3b expressing soluble methane monoxgenase. Appl Environ Microbiol 56, 28192826.

18. Peter, H. A. S., Nicholas, S. M., Sharpe, M. E. and Holt, J. F. 1986. Bergey's manual of systematic bacteriology, Williams and Wikins Co., Baltimore, Maryland.

19. Tamaoka, K. and Komagata, K. 1984. Determination of DNA base composition by reversed-phase high-performance liquid chromatography. FEMS Microbiol Lett 25, 125-128.

20. Tsien, H. C., Brusseau, G. A., Hanson, R. S. and Wackett, L. P. 1989. Biodegradation of trichloroethylene, dichloroethylene by Methylosinus trichosporium OB3b. Appl Environ Microbiol 55, 3155-3161.

\section{초록 : 유기염소계 난분해성 산업폐수의 처리를 위한 미생물제제의 개발}

이현돈 · 임성원 · 서현효*

(국립경남과학기술대학교 환경공학과)

유기염소계 난분해성 산업폐수처리에 효과적인 미생물제제 개발을 위하여 PCP (pentachlorophenol)와 TCE (trichloroethylene) 등과 같은 유기계 염소화합물이 오염되어있는 토양 및 산업폐수로부터 PCP 분해활성이 높은 $\mathrm{GP5}, \mathrm{GP} 19$ 와 TCE 분해활성이 높은 GA6, GA15를 분리하였다. 이들 분리균주 GP5, GP19, GA6, GA15등은 Acetobactor sp., Pseudomonas sp., Arthrobacer sp., Xanthomonas sp.과 유사한 것으로 나타나 최종적으로 Acetobacter sp. GP5, Pseudomonas sp. GP19, Arthrobacer sp. GA6, Xanthomoas sp. GA15로 명명하였다. 유기염소계 산업폐수의 처리를 위한 복합미생물제제 $\mathrm{OC} 17$ 은 $\mathrm{PCP}$ 와 TCE를 분해하는 4 개의 분리 분리균주와 방향족화합물 분해균주인 Acinetobacter sp. KN11, Neisseria sp. GN13의 배양액을 혼합하여 제조하였다. 복합미생물제제 OC17은 $2.8 \times 10^{9}$ $\mathrm{CFU} / \mathrm{g}$ 의 균체수를 갖고 있으며, 밀도는 $0.299 \mathrm{~g} / \mathrm{cm}^{3}$, 수분함량은 $26.8 \%$ 를 나타내었다. 복합미생물 제제 OC17은 PCP $500 \mathrm{mg} / 1$ 가 포함되어있는 인공폐수를 이용한 실험에서 배양 65 시간에 $87 \%$ 의 분해효율을 나타내었고, TCE $(300 \mathrm{uM})$ 의 분해효율은 배양 50 시간에 $90 \%$ 의 분해효율을 나타내었다. 복합미생물제제 OC17을 이용한 유기 염소 계 산업폐수의 처리효율 시험을 위한 연속배양 실험 에서 10 일간 처리 하였을 때 $91 \%$ 의 COD 제거효율을 나타내 었다. 